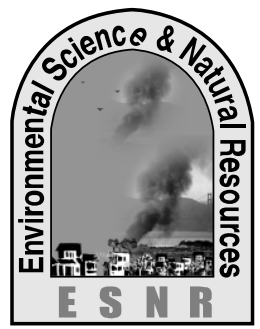

\title{
Chemical Properties of Buriganga and Turag River Water
}

\author{
N. Nawshin ${ }^{1}$, N. Sultana ${ }^{1}$, M. A. H. Chowdhury ${ }^{2}$ and M. A. Baten ${ }^{1 *}$ \\ ${ }^{1}$ Dept. of Environmental Science, ${ }^{2}$ Dept. of Agricultural Chemistry, \\ Bangladesh Agricultural University, Mymensingh-2202 \\ *Corresponding author: baten_envsc@yahoo.com
}

\begin{abstract}
The present study was undertaken to evaluate the chemical properties of Buriganga and Turag river water, Bangladesh. Water samples were collected from 15 locations of each river from January to February, 2016 to analyze chemical properties, which includes: $\mathrm{pH}$, EC, TDS, DO, cations $\left(\mathrm{Na}^{+}, \mathrm{K}^{+}, \mathrm{Ca}^{2+}, \mathrm{Mg}^{2+}\right)$, Anions $\left(\mathrm{Cl}^{-}, \mathrm{HCO}_{3}^{-}, \mathrm{SO}_{4}{ }^{2-}, \mathrm{CO}_{3}^{-}, \mathrm{PO}_{4}{ }^{3-}\right)$ and heavy metal contents $(\mathrm{Pb}, \mathrm{Cd}, \mathrm{Ni}, \mathrm{Cr}, \mathrm{As}, \mathrm{Zn}$, $\mathrm{Cu}$ ). The average value of $\mathrm{pH}$ was 8.47 and 8.41 in Buriganga and Turag water indicating moderate alkalinity. The average values of EC content of Buriganga and Turag river water were 327 and $272 \mu \mathrm{S} \mathrm{cm}^{-1}$ indicating low to moderate salinity. The mean values of TDS and DO content were 1468.4 and $2.93 \mathrm{mg} \mathrm{L}^{-1}$ in Buriganga river water and 1202 and $3.91 \mathrm{mg} \mathrm{L}^{-1}$ in Turag river water, respectively. Average concentration of $\mathrm{Pb}, \mathrm{Cd}, \mathrm{Ni}, \mathrm{Cr}, \mathrm{As}, \mathrm{Zn}$, and $\mathrm{Cu}$ found in Buriganga and Turag river water were 0.068, 0.016, $0.081,0.237,0.006,0.473,0.19 \mathrm{mg} \mathrm{L}^{-1}$ and $0.012,0.021,0.015,0.034,0.002,0.075,0.014 \mathrm{mg} \mathrm{L}^{-1}$, respectively. From the study it is found that the value of $\mathrm{Pb}, \mathrm{Cd}$ and $\mathrm{Cr}$ content in Buriganga and $\mathrm{Cr}$ content in Turag river water exceeded the standard limits of DoE and WHO. Therefore, Government and local people should take some effective measures to control the pollution of Buriganga and Turag river.
\end{abstract}

Key words: Buriganga river, Turag river, Water pollution and Heavy metal contents

\section{Introduction}

Water is the most important element to support life of living organisms on the earth. Out of $75 \%$ water on the earth, only $1 \%$ fresh water is available for drinking and other working purpose for living organisms. River water is one of the source of fresh water on the earth. However, river water become polluted by the disposing of industrial effluents, human wastes, household wastes, market wastes, sewage systems, municipal wastes and many other different ways. Polluted water contains different types of cations, anions and heavy metal which exceeded the standard limits of different national and international levels.

Buriganga and Turag are two main rivers in our country for industrialization because most of the industries build up on the bank of these two rivers. Buriganga river is aslo used for transportation system. These two rivers waters are used for irrigating crops and vegetables cultivated on the bank of these rivers areas.

But Buriganga and Turag river waters are polluted by the disposing of industrial effluents, municipal wastes, household wastes, and oil spill from water vehicles and so on. About 1172 industrial entities are polluting the Buriganga and the tanneries of Hazaribag is one of the major sources. (Anonymous, 1997). According to the Department of the Environment (DoE), 22,000 liters $(5,800$ US gal) of toxic wastes are released into the river by the tanneries every day (Brady and Tara, 2014). Ittefaq (2005) reported that the degree of pollution in Turag River at Tongi area was alarming due to the discharge of untreated industrial effluents and chemicals directly to the river. There are about 149 tanneries in Hazaribagh which generate about 18,000 liters liquid and about 115 metric tons solid waste daily. Almost all of which get released into the Turag river through Bashila and Katasur khals (Hossain, 2011).
High amount of heavy metals such as lead $(\mathrm{Pb})$, cadmium $(\mathrm{Cd})$, nickel $(\mathrm{Ni})$, chromium $(\mathrm{Cr})$, arsenic (As), zinc $(\mathrm{Zn})$, copper $(\mathrm{Cu})$ and many others are released by the industrial, municipals and household sectors. The high concentrations of these metals may accumulate and create toxicity for aquatic environment. According to Saha and Hossain (2011), exposure to heavy metals has linked to several human diseases such as development retardation or malformation, kidney damage, cancer, abortion, effect on intelligence and behavior, and even death in cases of exposure to very high concentrations.

Keeping all this views in mind, the study was conducted to assess the present status of heavy metal concentration of Buriganga and Turag river water which creating different types of problems (drinking, cooking, washing clothes, growing vegetables etc.) in the life of human beings.

\section{Materials and Methods}

\section{Study areas}

Study areas were Kamranggir char is a bank of Buriganga river and Abdullahpur is a bank of Turag river. 15 points were selected from each area. The selected areas of Kamranggir char (BP-1 to BP-15) situated from $23^{\circ} 43^{\prime} 41.03^{\prime} ' \mathrm{~N}$ to $23^{\circ} 42^{\prime} 30.43^{\prime} ' \mathrm{~N}$ latitude and $90^{\circ} 211^{\prime} 26.96{ }^{\prime \prime} \mathrm{E}$ to $90^{\circ} 23^{\prime} 31.11^{\prime \prime} \mathrm{E}$ longitude. The selected areas of Abdullahpur (TP-1 to TP-15) were latitude from $23^{\circ} 52^{\prime} 55.60^{\prime \prime} \mathrm{N}$ to $23^{\circ} 52^{\prime} 50.97^{\prime \prime} \mathrm{N}$ and $90^{\circ} 24^{\prime} 20.06^{\prime \prime} \mathrm{E}$ to $90^{\circ} 23^{\prime} 46.09^{\prime}{ }^{\prime} \mathrm{E}$ longitude (Fig. 1). Both of these areas were so much polluted by the industrial untreated effluents, municipal waste, market waste, spill oil from water vehicles and sewage drainage. 


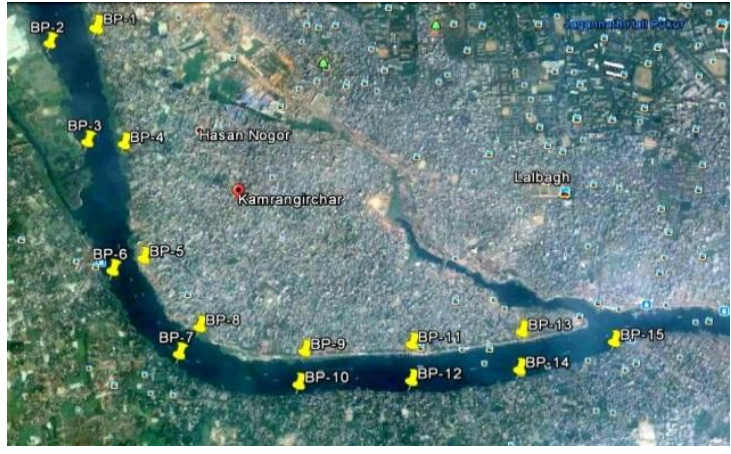

(A)

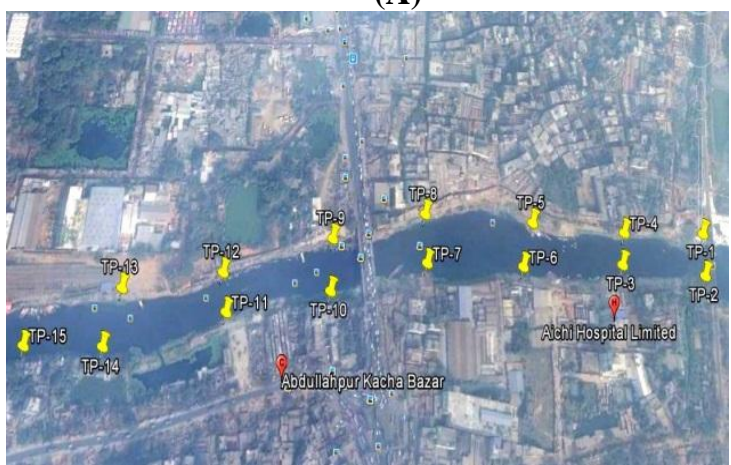

(B)

Fig. 1. Sampling locations (A) Burignaga river (B) Turag river

(Source: Google Earth)

\section{Instruments}

pH meter, EC meter, TDS meter, Atomic Absorption Spectrophotometer, DO meter, some 1 liter fresh water bottles, filter paper, conical flusk, burette, pipette, buffer solution, distilled water were used for the physico-chemical analysis.

\section{Water sample collection and preparation}

Water samples were collected from Kamranggir char and Abdullahpur under the district of Dhaka and Gazipur. For collecting water samples, at first water bottles were cleaned with Hydrochloric acid ( $\mathrm{HCl})(1: 1)$ and washed with distill water then sealed tightly to avoid exposure to air. Out of 30 samples, 15 samples were collected from surface water of river Buriganga and other 15 samples were collected from surface water of Turag river with their replicants for finding better result. Water samples filtered with filter paper (Whatman No. 1) to remove undesirable solid and suspended materials. Few drops of Toluene added in the samples which created a chemical layer to prevent the growth of micro-organisms in the presence of sunlight. Samples were preserved in refrigerator at $-18^{\circ} \mathrm{C}$ for chemical analysis.

\section{Sample analysis}

$\mathrm{pH}, \mathrm{EC}, \mathrm{TDS}, \mathrm{DO}$ contents, cations and anions in water samples were analyzed with different instruments in the Dept. of Agricultural Chemistry, BAU and heavy metal contents were analyzed in the Soil Division of Bangladesh Agricultural Research Institute (BARI), Gazipur, Bangladesh. For heavy metal analysis using Atomic Absorption Spectrophotometer (Model no: SpectrAA-55B). $\mathrm{Na}^{+}$and $\mathrm{K}^{+}$anions were analyzed with flame emission spectrophotometer. Stannous Chloride method, Turbidimetric method, Azantometric methods were used for the analysis of $\mathrm{PO}_{4}{ }^{3-}, \mathrm{SO}_{4}{ }^{2-}, \mathrm{Cl}^{-}$, and $\mathrm{Ca}^{2+}$. $\mathrm{Mg}^{2+}$ was analyzed by the process of EDTA titrimetric method.

\section{Data analysis}

All the collected data were processed in the software MS word, MS Excel and using picasa 3. for editing the figures.

\section{Results and Discussion}

pH

From the analysis, $\mathrm{pH}$ values of Buriganga and Turag river water ranged from 7.77-9.04 and 7.50-9.00, respectively (Table 1). Highest value of $\mathrm{pH}$ was found at the point no BP-11 in Buriganga and at the point no TP-6 in Turag river water.

Table 1. $\mathrm{pH}, \mathrm{EC}, \mathrm{TDS}$ and DO contents of collected water samples of Buriganga and Turag river water.

\begin{tabular}{|c|c|c|c|c|c|c|}
\hline $\begin{array}{c}\text { Serial } \\
\text { No. }\end{array}$ & River name & $\begin{array}{c}\text { Mean \& } \\
\text { Range }\end{array}$ & $\mathbf{p H}$ & $\begin{array}{c}\mathbf{E C} \\
\left(\boldsymbol{\mu} \mathbf{S} \mathbf{~ c m}^{-\mathbf{1}}\right)\end{array}$ & $\begin{array}{c}\mathbf{T D S} \\
\left(\mathbf{m g ~ L}^{-\mathbf{1}}\right)\end{array}$ & $\begin{array}{c}\mathbf{D O} \\
\left(\mathbf{m g ~ L}^{-\mathbf{1}}\right)\end{array}$ \\
\hline $\mathbf{1}$ & \multirow{2}{*}{$\begin{array}{c}\text { Buriganga } \\
\text { river }\end{array}$} & Mean & 8.47 & 327 & 1468.4 & 2.93 \\
\cline { 3 - 7 } & Range & $7.77-9.04$ & $106-731$ & $475-3276$ & $1.1-5.1$ \\
\hline \multirow{2}{*}{} & Turag river & Mean & 8.41 & 272 & 1202 & 3.91 \\
\cline { 3 - 7 } & & Range & $7.50-9.00$ & $136-574$ & $620-2644$ & $1.9-5.8$ \\
\hline
\end{tabular}

$E C$

From the Table 1, the average values of EC content of Buriganga and Turag river water were 327 and $272 \mu \mathrm{S}$ $\mathrm{cm}^{-1}$ introducing the low to moderate salinity of both river water. The highest and the lowest values of EC contents in Buriganga and Turag river water were found at the point no BP-7, TP-13 and BP-10, TP-4, respectively.
The highest values of TDS contents were found at the location of BP-7 (3276 mg L-1) in Buriganga and TP-13 (2644 $\mathrm{mg} \mathrm{L}^{-1}$ ) in Turag river water which crossed the limits of WHO standard. The lowest values of TDS were 475 and $620 \mathrm{mg} \mathrm{L}^{-1}$ in Buriganga and Turag river, respectively. 


\section{DO}

DO is a very important parameter of water which deficiency creating problem to aquatic life. According to DoE (2005), the standard value of DO for river water is $6 \mathrm{mg} \mathrm{L}^{-1}$ But from the Fig. 2 it is found that the average DO content of Buriganga and Turag river water were lower than the DoE standard.

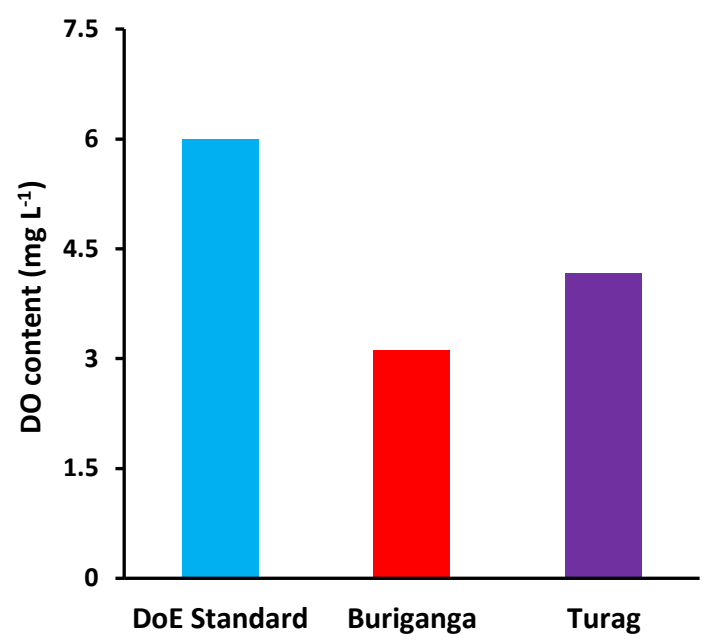

Fig. 2. Average DO contents of Buriganga and Turag river water compared with DOE standard.

\section{Anion contents}

The anions contents of Buriganga and Turag river water at different sampling location is presented in Table 2 . Average values of $\mathrm{Cl}^{-}, \mathrm{HCO}_{3}{ }^{-}, \mathrm{SO}_{4}{ }^{2-}, \mathrm{CO}_{3}{ }^{-}$, and $\mathrm{PO}_{4}{ }^{3-}$ contents of Buriganga river water were 922, 6.63, 251.6, 1.06, $5.63 \mathrm{mg} \mathrm{L}^{-1}$ and those of Turag river water were $537,4.24,236.1,0.93,3.06 \mathrm{mg} \mathrm{L}^{-1}$, respectively.

\section{Cation contents}

Table 2 represents the different amount of cation contents at different points of Buriganga and Turag river water. The mean values of $\mathrm{Na}^{+}, \mathrm{K}^{+}, \mathrm{Ca}^{2+}$, and $\mathrm{Mg}^{2+}$ contents of Buriganga and Turag river water were $165,2.94,79.13,20.02 \mathrm{mg} \mathrm{L}^{-1}$ and $133,2.13,51.22$ and $11.42 \mathrm{mg} \mathrm{L}^{-1}$ respectively.

\section{$\mathrm{Pb}$ and $\mathrm{Cd}$ contents}

The concentration of $\mathrm{Pb}$ and $\mathrm{Cd}$ contents in Buriganga varied from 0.038 to $0.098 \mathrm{mg} \mathrm{L}^{-1}$ and from 0.007 to $0.026 \mathrm{mg} \mathrm{L}^{-1}$ with average values of 0.068 and 0.016 $\mathrm{mg} \mathrm{L}^{-1}$. For Turag river water, the concentrations of $\mathrm{Pb}$ and $\mathrm{Cd}$ contents were ranged from 0.001 to $0.019 \mathrm{mg} \mathrm{L}^{-}$ 1 and from 0.001 to 0.15 with average values of 0.012 and $0.021 \mathrm{mg} \mathrm{L}^{-1}$, respectively (Table 3). Ahmed et al. (2010) found the average value of $\mathrm{Pb} 0.065 \mathrm{mg} \mathrm{L}^{-1}$ in Buriganga river water. From the Fig. 3 it is found that the average value of $\mathrm{Pb}$ content in Buriganga river water was higher than the FAO, WHO and Bangladesh standard limits.

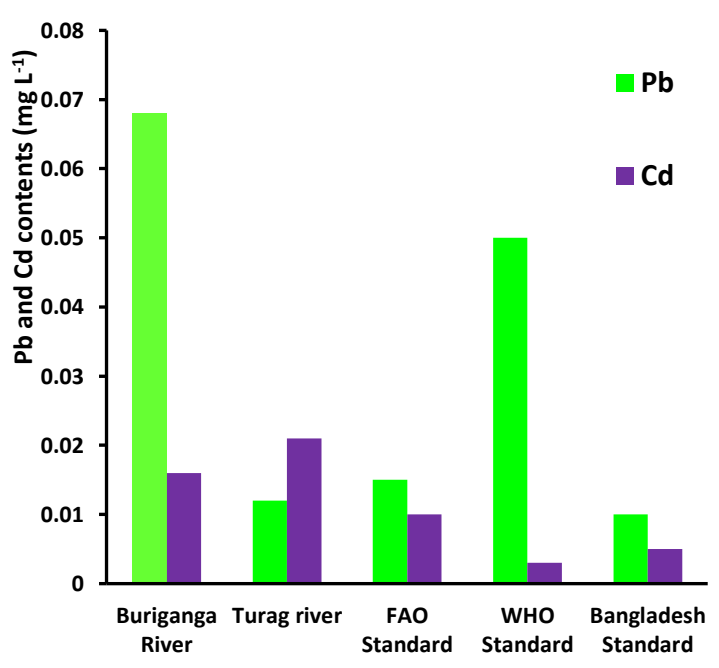

Fig. 3. Average $\mathrm{Pb}$ and $\mathrm{Cd}$ contents of Buriganga and Turag river water with different standards.

It was also higher than the Turag river water. The mean value of $\mathrm{Cd}$ content of Turag river water was higher than the Buriganga river water and also higher than different national and international limits.

\section{Ni and Cr contents}

The mean concentration of $\mathrm{Ni}$ and $\mathrm{Cr}$ content of Buriganga river water were 0.081 and $0.237 \mathrm{mg} \mathrm{L}^{-1}{ }^{1}$.

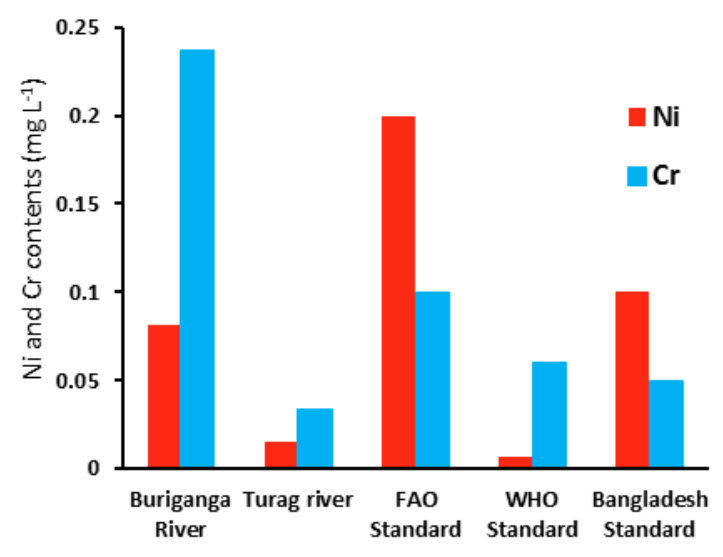

Fig. 4. Average $\mathrm{Ni}$ and $\mathrm{Cr}$ contents of Buriganga and Turag river water with different standards.

with a ranged from 0.003 to $1.03 \mathrm{mg} \mathrm{L}^{-1}, 0.089$ to 0.591 $\mathrm{mg} \mathrm{L}^{-1}$. The average values of $\mathrm{Ni}$ and $\mathrm{Cr}$ contents in Turag river water were 0.015 and $0.034 \mathrm{mg} \mathrm{L}^{-1}$ with ranged from 0.011 to 0.025 and 0.002 to $0.075 \mathrm{mg} \mathrm{L}^{-1}$, respectively (Table 3 ). Fig. 3 represents the $\mathrm{Cr}$ content in Buriganga river water is crossed the FAO, WHO and Bangladesh Standard.

\section{$\mathrm{Zn}$ and $\mathrm{Cu}$ contents}

The values of $\mathrm{Zn}$ content of collected water samples from Buriganga river were fluctuated from 0.191 to $0.847 \mathrm{mg} \mathrm{L}^{-1}$ with mean value of $0.473 \mathrm{mg} \mathrm{L}^{-1}$ and $\mathrm{Cu}$ contents ranged from 0.128 to $0.247 \mathrm{mg} \mathrm{L}^{-1}$ with mean value of $0.19 \mathrm{mg} \mathrm{L}^{-1}$, respectively (Table 3 ). The highest value of $\mathrm{Zn}$ content was found in Buriganga 
river water at the location no $\mathrm{BP}-11$ and the lowest value was found at the point no BP-1.

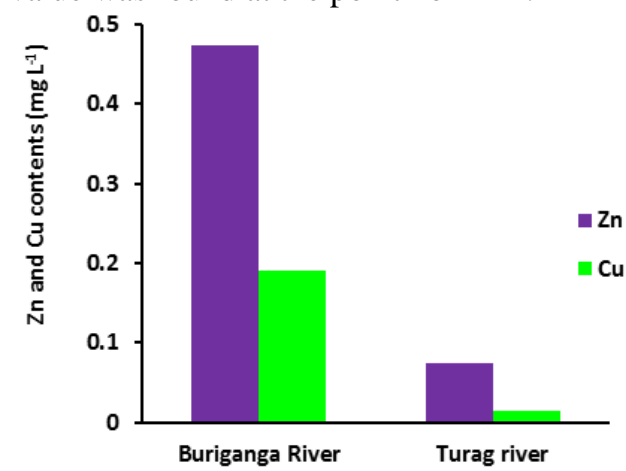

Fig. 5. Average $\mathrm{Ni}$ and $\mathrm{Cr}$ contents of Buriganga and Turag river water.

The $\mathrm{Zn}$ content of Turag water samples ranged from 0.029 to $0.131 \mathrm{mg} \mathrm{L}^{-1}$ with mean value of $0.075 \mathrm{mg} \mathrm{L}^{-1}$ and $\mathrm{Cu}$ content ranged from 0.006 to $0.025 \mathrm{mg} \mathrm{L}^{-1}$ with mean value of $0.014 \mathrm{mg} \mathrm{L}^{-1}$, respectively.

The $\mathrm{Zn}$ and $\mathrm{Cu}$ content of Buriganga river water was higher than the Turag river water (Fig. 4). Mohiuddin et al. (2016) found that the $\mathrm{Zn}$ content in Buriganga river water samples ranged from 0.204 to $0.821 \mathrm{mg} \mathrm{L}^{-1}$ with mean value of $0.399 \mathrm{mg} \mathrm{L}^{-1}$. Zakir et al. (2006) found that the $\mathrm{Zn}$ content of Turag river water at eastern part ranged from 0.063 to $0.121 \mathrm{mg} \mathrm{L}^{-1}$ and at the western part ranged from 0.049 to $0.101 \mathrm{mg} \mathrm{L}^{-1}$.

\section{As content}

The average As content of Buriganga and Turag river water was 0.06 and $0.02 \mathrm{mg} \mathrm{L}^{-1}$, respectively (Fig. 6). From the average As content of Buriganga river water was higher than the Turag river water.

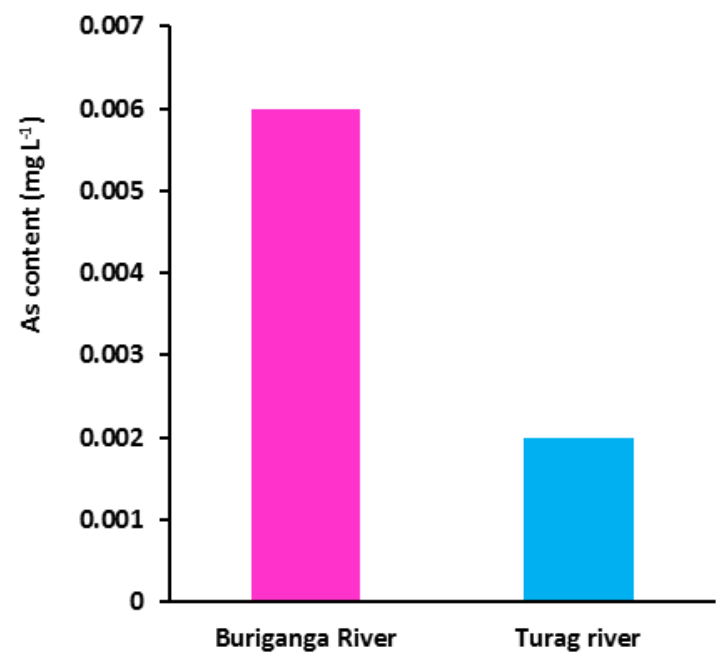

Fig. 6. Average As content of Buriganga and Turag river water.

Table 2. Anion and cation contents of some water samples of Buriganga and Turag river water

\begin{tabular}{|c|c|c|c|c|c|c|c|c|c|c|}
\hline $\begin{array}{l}\text { River } \\
\text { name }\end{array}$ & $\begin{array}{c}\text { Sampli } \\
\text { ng } \\
\text { points }\end{array}$ & $\mathrm{Cl}^{-}$ & $\mathrm{HCO}_{3}^{-}$ & $\mathrm{SO}_{4}{ }^{2-}$ & $\mathrm{CO}_{3}^{-}$ & $\mathrm{PO}_{4}{ }^{3-}$ & $\mathrm{Na}^{+}$ & $\mathbf{K}^{+}$ & $\mathrm{Ca}^{2+}$ & $\mathrm{Mg}^{2+}$ \\
\hline \multirow{15}{*}{ 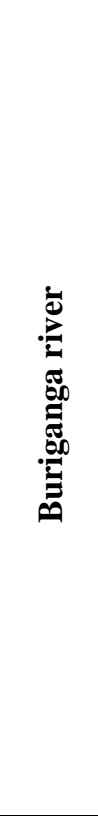 } & BP-1 & 659 & 6.0 & 165.3 & 0.02 & 1.0 & 154.8 & 2.48 & 64.65 & 22.61 \\
\hline & BP-2 & 260 & 2.0 & 97.9 & 0.18 & 1.4 & 52.51 & 0.83 & 22.22 & 14.60 \\
\hline & BP-3 & 660 & 6.4 & 189.0 & 1.30 & 0.5 & 142.0 & 2.24 & 89.53 & 18.88 \\
\hline & BP-4 & 760 & 5.4 & 220.7 & 0.90 & 6.7 & 147.5 & 2.86 & 95.25 & 15.37 \\
\hline & BP-5 & 2099 & 16.1 & 520.4 & 4.90 & 0.8 & 357.4 & 6.09 & 102.7 & 42.42 \\
\hline & BP-6 & 2639 & 13.5 & 484.6 & 2.80 & 4.6 & 444.7 & 8.59 & 147.6 & 48.56 \\
\hline & BP-7 & 2559 & 14.4 & 505.5 & 1.70 & 11.5 & 380.3 & 6.45 & 156.9 & 55.46 \\
\hline & BP-8 & 739 & 5.5 & 192.8 & 1.10 & 9.6 & 132.8 & 2.02 & 70.64 & 19.26 \\
\hline & BP-9 & 500 & 3.8 & 170.6 & 0.45 & 10.4 & 95.08 & 1.49 & 99.36 & 3.70 \\
\hline & BP-10 & 439 & 3.7 & 278.4 & 0.40 & 1.2 & 105.4 & 1.56 & 43.46 & 18.68 \\
\hline & BP-11 & 360 & 3.1 & 223.8 & 0.37 & 0.7 & 85.09 & 1.34 & 51.90 & 9.59 \\
\hline & BP-12 & 280 & 2.8 & 202.0 & 0.23 & 0.1 & 68.45 & 1.00 & 41.07 & 12.67 \\
\hline & BP-13 & 800 & 6.0 & 268.9 & 0.05 & 14.3 & 111.0 & 2.70 & 41.84 & 12.43 \\
\hline & BP-14 & 480 & 4.4 & 184.5 & 0.67 & 10.1 & 77.89 & 1.83 & 54.52 & 4.35 \\
\hline & BP-15 & 599 & 6.3 & 69.3 & 0.90 & 11.4 & 119.5 & 2.56 & 105.2 & 1.68 \\
\hline \multicolumn{2}{|c|}{ Mean } & 922 & 6.63 & 251.6 & 1.06 & 5.63 & 165 & 2.94 & 79.13 & 20.02 \\
\hline \multicolumn{2}{|c|}{ Range } & $\begin{array}{l}260- \\
2639 \\
\end{array}$ & $2-16.1$ & $69-520$ & $\begin{array}{l}0.02- \\
4.90\end{array}$ & $\begin{array}{l}0.1- \\
14.3 \\
\end{array}$ & $\begin{array}{l}52.51- \\
444.7 \\
\end{array}$ & $\begin{array}{l}0.83- \\
8.59 \\
\end{array}$ & $\begin{array}{l}22.2- \\
156.9\end{array}$ & $\begin{array}{l}1.68- \\
55.46\end{array}$ \\
\hline \multirow{2}{*}{ 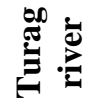 } & TP-1 & 1999 & 11.3 & 520.8 & 3.70 & 3.9 & 561.5 & 8.32 & 67.27 & 21.44 \\
\hline & TP-2 & 439 & 3.0 & 386.8 & 2.10 & 0.4 & 128.4 & 1.73 & 82.99 & 4.97 \\
\hline
\end{tabular}




\begin{tabular}{|c|c|c|c|c|c|c|c|c|c|c|}
\hline & TP-3 & 240 & 6.2 & 387.7 & 0.59 & 3.5 & 211.4 & 2.17 & 48.07 & 25.93 \\
\cline { 2 - 10 } & TP-4 & 320 & 3.4 & 244.5 & 0.34 & 0.4 & 76.19 & 1.48 & 41.26 & 11.88 \\
\cline { 2 - 10 } & TP-5 & 339 & 2.9 & 222.3 & 0.12 & 0.3 & 88.14 & 1.04 & 22.90 & 17.37 \\
\hline TP-6 & 199 & 1.0 & 130.0 & 0.00 & 0.5 & 33.19 & 0.64 & 33.31 & 6.65 \\
\hline TP-7 & 179 & 1.4 & 110.2 & 0.01 & 0.0 & 25.22 & 0.54 & 64.54 & 2.38 \\
\hline TP-8 & 359 & 2.8 & 281.1 & 0.21 & 0.1 & 90.81 & 1.28 & 60.90 & 11.57 \\
\hline TP-9 & 379 & 4.4 & 134.1 & 1.09 & 0.9 & 75.25 & 1.52 & 64.27 & 9.41 \\
\hline TP-10 & 500 & 3.7 & 211.6 & 0.87 & 0.0 & 118.2 & 1.65 & 32.28 & 10.98 \\
\hline TP-11 & 340 & 2.0 & 198.4 & 0.09 & 0.2 & 80.27 & 1.64 & 70.66 & 1.96 \\
\hline TP-12 & 399 & 3.4 & 267.2 & 0.02 & 0.2 & 111.7 & 1.40 & 67.51 & 13.21 \\
\hline TP-13 & 1619 & 12.4 & 402.0 & 3.64 & 11.5 & 265.6 & 5.71 & 51.18 & 24.09 \\
\hline TP-14 & 399 & 3.3 & 21.5 & 0.75 & 12.2 & 69.37 & 1.40 & 22.75 & 6.78 \\
\hline TP-15 & 340 & 2.4 & 23.2 & 0.36 & 11.6 & 57.17 & 1.40 & 38.37 & 2.72 \\
\hline Mean & 537 & 4.24 & 236.1 & 0.93 & 3.06 & 133 & 2.13 & 51.22 & 11.42 \\
\hline
\end{tabular}

Table 3. Heavy metal contents of some water samples of Buriganga and Turag river water

\begin{tabular}{|c|c|c|c|c|c|c|c|c|}
\hline \multicolumn{9}{|c|}{ Heavy metal contents $\left(\mathrm{mg} \mathrm{L}^{-1}\right)$} \\
\hline $\begin{array}{l}\text { River } \\
\text { name }\end{array}$ & $\begin{array}{c}\text { Sampling } \\
\text { points }\end{array}$ & $\mathbf{P b}$ & Cd & $\mathbf{N i}$ & $\mathrm{Cr}$ & As & $\mathbf{Z n}$ & $\mathrm{Cu}$ \\
\hline \multirow{15}{*}{ 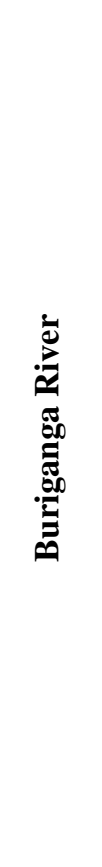 } & BP-1 & 0.078 & 0.024 & 0.015 & 0.121 & 0.008 & 0.191 & 0.158 \\
\hline & BP-2 & 0.067 & 0.011 & 0.013 & 0.089 & 0.000 & 0.347 & 0.128 \\
\hline & BP-3 & 0.058 & 0.026 & 0.012 & 0.101 & Trace & 0.298 & 0.188 \\
\hline & BP-4 & 0.098 & 0.013 & 0.003 & 0.396 & 0.006 & 0.379 & 0.232 \\
\hline & BP-5 & 0.038 & 0.009 & 0.022 & 0.591 & 0.005 & 0.789 & 0.245 \\
\hline & BP-6 & 0.054 & 0.019 & 0.010 & 0.456 & 0.004 & 0.827 & 0.198 \\
\hline & BP-7 & 0.065 & 0.013 & 0.013 & 0.159 & Trace & 0.745 & 0.187 \\
\hline & BP-8 & 0.071 & 0.021 & 0.029 & 0.198 & 0.004 & 0.297 & 0.205 \\
\hline & BP-9 & 0.073 & 0.024 & 0.011 & 0.137 & 0.004 & 0.371 & 0.148 \\
\hline & BP-10 & 0.064 & 0.010 & 0.012 & 0.167 & 0.007 & 0.541 & 0.139 \\
\hline & BP-11 & 0.058 & 0.007 & 0.014 & 0.178 & 0.009 & 0.847 & 0.175 \\
\hline & BP-12 & 0.081 & 0.016 & 1.030 & 0.092 & 0.010 & 0.453 & 0.194 \\
\hline & BP-13 & 0.076 & 0.023 & 0.011 & 0.289 & Trace & 0.361 & 0.247 \\
\hline & BP-14 & 0.069 & 0.014 & 0.013 & 0.381 & 0.002 & 0.279 & 0.176 \\
\hline & BP-15 & 0.065 & 0.012 & 0.014 & 0.196 & 0.020 & 0.368 & 0.223 \\
\hline \multicolumn{2}{|c|}{ Range } & $\begin{array}{c}0.038- \\
0.098\end{array}$ & $\begin{array}{c}0.007- \\
0.026\end{array}$ & $\begin{array}{c}0.003- \\
1.03 \\
\end{array}$ & $\begin{array}{c}0.089- \\
0.591\end{array}$ & $\begin{array}{c}\text { Trace- } \\
0.02\end{array}$ & $\begin{array}{c}0.191- \\
0.847\end{array}$ & $\begin{array}{c}0.128 \\
0.247\end{array}$ \\
\hline \multicolumn{2}{|c|}{ Mean } & 0.068 & 0.016 & 0.081 & 0.237 & 0.006 & 0.473 & 0.19 \\
\hline \multirow{5}{*}{ 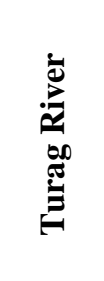 } & TP-1 & 0.017 & 0.150 & 0.013 & 0.035 & 0.002 & 0.064 & 0.014 \\
\hline & TP-2 & 0.011 & 0.018 & 0.013 & 0.014 & 0.001 & 0.049 & 0.006 \\
\hline & TP-3 & 0.012 & 0.002 & 0.014 & 0.016 & 0.003 & 0.104 & 0.019 \\
\hline & TP-4 & 0.019 & 0.014 & 0.014 & 0.045 & 0.001 & 0.029 & 0.011 \\
\hline & TP-5 & 0.001 & 0.016 & 0.025 & 0.017 & 0.001 & 0.125 & 0.008 \\
\hline
\end{tabular}




\begin{tabular}{|c|c|c|c|c|c|c|c|c|}
\hline & TP-6 & 0.009 & 0.015 & 0.013 & 0.023 & 0.004 & 0.071 & 0.018 \\
\cline { 2 - 9 } & TP-7 & 0.013 & 0.013 & 0.021 & 0.037 & 0.003 & 0.094 & 0.025 \\
\cline { 2 - 9 } & TP-8 & 0.006 & 0.014 & 0.012 & 0.043 & 0.002 & 0.089 & 0.006 \\
\hline TP-9 & 0.002 & 0.015 & 0.014 & 0.031 & 0.002 & 0.043 & 0.024 \\
\hline TP-10 & 0.018 & 0.015 & 0.012 & 0.002 & 0.001 & 0.052 & 0.009 \\
\hline TP-11 & 0.011 & 0.013 & 0.017 & 0.041 & 0.002 & 0.131 & 0.017 \\
\hline TP-12 & 0.017 & 0.012 & 0.011 & 0.047 & 0.003 & 0.064 & 0.011 \\
\hline TP-13 & 0.013 & 0.013 & 0.014 & 0.075 & 0.001 & 0.081 & 0.01 \\
\hline TP-14 & 0.016 & 0.011 & 0.013 & 0.068 & 0.001 & 0.072 & 0.007 \\
\hline TP-15 & 0.017 & 0.001 & 0.012 & 0.02 & 0.002 & 0.063 & 0.018 \\
\hline
\end{tabular}

Conclusions

From the present study, it has been found that the surface water of Buriganga and Turag river were highly polluted by the TDS contents which crossing the standard limits of WHO because of disposing huge amount of industrial effluents. The DO content of Buriganga river water was very lower than the standard limits of DoE which indicating threat to the aquatic life support system. Moreover in Buriganga river water, the concentrations of $\mathrm{Pb}, \mathrm{Cd}$ and $\mathrm{Cr}$ were higher than the standard limits. On the other hand the concentration of $\mathrm{As}, \mathrm{Zn}, \mathrm{Cu}, \mathrm{Ni}$ was lower than the irrigation standard limits of WHO and FAO. The amount of Cd $(0.021 \mathrm{mg}$ $\left.\mathrm{L}^{-1}\right)$ in Turag river water was crossed the standard limits because of dumping high amount of industrial wastes. In this condition, it is strongly recommended that the water of Buriganga and Turag river is hazardous for drinking purposes and creating risk to the human health. Both public and Government participation need to reduce the pollution of these rivers water and create awareness among the people about the serious consequences of rivers water pollution.

\section{References}

Ahammed, S. S.; Tasfina, S.; Rabbani, K. A. and Khaleque, M. A. 2016. International Journal of Scientific and Technology Research, 5(3): 36-41.

Anonymous, 1997. Industrial pollution a public health hazard (editorial column). The Bangladesh Observer, September 6, P.7.

Brady and Tara. 2014. Working themselves to death, the Bangladesh men and women tanning leather for a pittance in one of the world's top 30 most polluted locations. Daily Mail. Retrieved 24 March 2014.

Mohiuddin, K. M.; Alam, M. M.; Rahman, M. S.; Islam, M. S. and Ahmed, I. 2016. Effect of polluted river water on growth, yield and heavy metal accumulation of red amaranth. Research Agricultural Livestock Fish, 3(1): 53-65.

Zakir, H. M.; Sharmin, S. and Shikazono, N. 2006. Heavy metal pollution assessment in water and sediment of Turag river at Tongi area in Bangladesh. International Journal of Lakes and Rivers, 1(1): 8596.

DoE (Department of Environment). 2005. Government of the People's Republic of Bangladesh, Ministry of Environment and Forest, Department of Environment Dhaka, Bangladesh.

Hossain, M. S. 2011. Time to save the Turag from pollution. The Daily Star. http://www.thedailystar.net/news-detail-169135

Ittefaq (The Daily Ittefaq). 2005. A report on "Fish died in the polluted water of Turag: Flock of Seagulls in the sky" (in Bengali). Rajdhaneer Ashapasha, November 19, 2005, Bangladesh.

Saha and Hossain. 2011. Assessment of Heavy Metal Contamination and Sediment Quality in the Buriganga River, Bangladesh. International Conference on Environmental Science and Technology, 6: 384-388. 